\title{
Relationship between learning styles and learning achievement in mathematics based on genders
}

\author{
Abdul Rahman \& Ansari S. Ahmar \\ Universitas Negeri Makassar \\ Makassar, South Sulawesi, Indonesia
}

\begin{abstract}
This study was a descriptive study using cross sectional design. The aims of this research were to examine the relationship between learning styles and learning outcomes by gender. The population in this study were all students in 1st year of SMAN 1 Galesong Selatan, Indonesia, in the 2014/2015 academic year. The instruments used in this research was the test of modalities learning styles (TMLS), to determine whether the students' learning styles are visual, auditory and kinaesthetic (VAK), and documentation. The relationship between learning styles and learning outcomes were analysed with the chi-square test and two-way ANOVA. The results of this study showed that 1) the learning styles of visual and auditory learning styles is dominated by women; and 2) there is no relationship between the variables of learning styles, genders and interaction of learning styles with genders to learning achievement.
\end{abstract}

\section{INTRODUCTION}

It is important to support the future with education in the current era. A good future will be secured if someone has a good education and skills. To reach a higher standard of education, students need many adaptations before mastering an advance cognitive skill [1].

In the process of learning, each person has specific learning characteristics. The characteristics of each person are different. One of the distinct characteristics is learning style. Learning styles are associated with the ability to absorb and process the results of learning acquired by a student. Learning style is an important factor for determining the outcome of student learning. Learning style is the way the nature of the individual is involved in them acquiring and absorbing information in their environment. Learning styles affect the students' learning process so that it can be used as a consideration in designing learning [2].

Learning style is an important modality in the learning process. Modalities are often associated with learning styles. The modalities are usually associated with how students use their senses in the learning process. In general, there are three types of modalities; namely, visual, auditory and kinaesthetic [3][4]. Important polemic discussions have been aware of gender differences in cognitive mapping that reflects the ability to reproduce the spatial environment and objects [5]. Gender differences in mathematics is somewhat controversial, but there is considerable evidence that shows that men often outperform women on tests of mathematics achievement, particularly at high school and among the university population [6-10].

\section{LITERATURE REVIEW}

\section{Learning Styles}

The development of one's personality usually depends on learning styles and is often influenced by environmental, emotional, social influence and individual feelings. How to learn is different for each person. Some learners need to see more; some need to hear, and some have to do something to the body using a series of activities. Rahman et al stated that in general, the learning style of each person consists of three types of visual style, auditory style and kinaesthetic style [2]. The types are as follows:

Visual learning style. Rahman et al said that the visual learning style is a learning style through which people learn best when they see images of what they are learning; they are oriented to printed text and can learn through reading [2]. Visual learners think in pictures and learn best through visual images. Individuals who have a visual learning style are well marked with behavioural characteristics as follows: 
- $\quad$ neat and tidy;

- $\quad$ speaking quickly;

- $\quad$ planner and regulator of long-term is good;

- meticulous to detail;

- $\quad$ concerned with the appearance, both in terms of clothing and presentation;

- $\quad$ good speller and can see the actual words in their minds;

- $\quad$ given what is seen rather than what is heard [11].

Auditory learning style. Rahman et al said that auditory learning style is a learning style in which people learn better when they hear what they are learning [2]. Individuals who have an auditory learning style are well marked with behavioural characteristics as follows:

- $\quad$ talking to yourself at work;

- $\quad$ easily distracted by a commotion;

- $\quad$ they move their lips and read out loud when reading;

- $\quad$ glad to read aloud and listen;

- $\quad$ can repeat back and mimicked the tone, rhythm and timbre;

- $\quad$ find it difficult to write, but great storytelling;

- $\quad$ speaking in a patterned rhythm [11].

Kinaesthetic learning style. Kinaesthetic learning style is a style of learning by engaging, moving, experiencing and experimenting [12]. Individuals who have a kinaesthetic learning style are well marked with behavioural characteristics as follows:

- $\quad$ speak slowly;

- $\quad$ responding to physical attention;

- $\quad$ touching people to get their attention;

- $\quad$ stand close when talking to people;

- $\quad$ always physically oriented and a lot of moves;

- $\quad$ has the early development of large muscles;

- $\quad$ learning through manipulating and practices [11].

\section{METHOD}

This study was a descriptive study using cross sectional design. The population in this study were all students in 1st Year of SMAN 1 Galesong Selatan, Indonesia, in the 2014/2015 academic year. The random sampling method was used in this study, and there were 34 students in the sample. Instruments used in this research were the test of modalities learning styles (TLMS) to determine whether the students' learning styles are visual, auditory and kinaesthetic (VAK), and documentation. The relationship between learning styles and learning outcomes was analysed with the chi-square test and two-way ANOVA.

\section{RESULT AND DISCUSSION}

Based on results of the test of modalities learning styles, the student's learning style can be seen in Table 1 and Figure 1.

Table 1: Result of results of the test of modalities learning styles.

\begin{tabular}{|l|c|c|c|c|c|c|}
\hline \multirow{2}{*}{ Style } & \multicolumn{2}{|c|}{ Male } & \multicolumn{2}{c|}{ Female } & \multicolumn{2}{c|}{ Total } \\
\cline { 2 - 7 } & $\mathrm{N}$ & Pearson & $\mathrm{N}$ & Pearson & $\mathrm{n}$ & Pearson \\
\hline Visual & 7.00 & 41.18 & 3.00 & 17.65 & 10.00 & 29.41 \\
\hline Auditory & 10.00 & 58.82 & 7.00 & 41.18 & 17.00 & 50.00 \\
\hline Kinaesthetic & 4.00 & 23.53 & 3.00 & 17.65 & 7.00 & 20.59 \\
\hline \multicolumn{3}{|c|}{ Total } & 34.00 & 100.00 \\
\hline
\end{tabular}

From the test results (Table 1 and Figure 1), it can be seen that from the 34 students who did the test, ten students (29.41\%) have a visual learning style, seven students (20.59\%) have an auditory learning style, and 17 students (50\%) have a kinaesthetic learning style. From the results of this test it also seems that the visual and auditory learning styles are dominated by women, in the sense that female students are more likely to like learning from graphs, charts, flow diagrams, speech and hearing.

This is in agreement with the results of research conducted by Kharb et al [13] and also Csapo and Hayen [14]. Kharb et al said that a significantly higher number of female students prefer auditory learning styles compared to male 
students [13]. Furthermore, Csapo and Hayen said that female students scored higher in the strength of visual and auditory learning styles over male students [14].

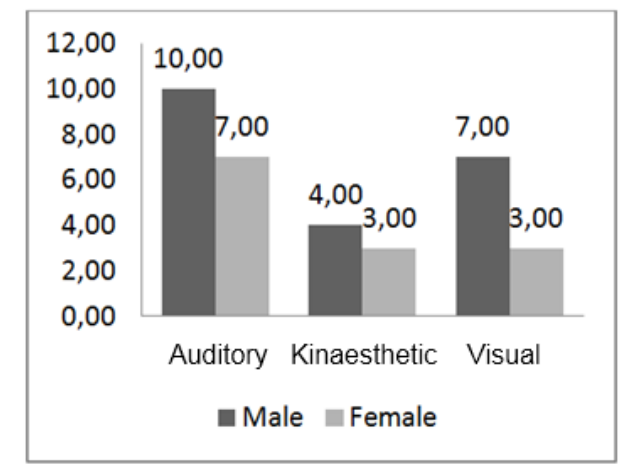

Figure 1: Histogram of results of the test of modalities learning styles.

Table 2: Chi-square tests of learning styles and learning achievement of mathematics.

\begin{tabular}{|l|c|c|c|}
\hline \multicolumn{3}{|c|}{ Chi-square tests } \\
\hline & Value & df & $\begin{array}{c}\text { Asymp. sig. } \\
\text { (2-sided) }\end{array}$ \\
\hline Pearson chi-square & $42.629^{\mathrm{a}}$ & 38 & 0.279 \\
\hline Likelihood ratio & 47.988 & 38 & 0.129 \\
\hline Linear-by-linear association & 0.864 & 1 & 0.353 \\
\hline N of valid cases & 34 & & \\
\hline
\end{tabular}

Note: 60 cells $(100,0 \%)$ have expected count less than 5 . The minimum expected count is 0.21

The results of the analysis using the chi-square test show that the value of sig. (2-sided): $0.279>\alpha=0.05$ which means that there is no significant relationship between learning styles and learning achievement in 1st year of SMAN 1 Galesong Selatan, Indonesia. This is in agreement with the opinion Ahmad et al [15] and Yilmaz-Soylu and Akkoyunlu [16]. Ahmad et al [15] said that there was no significant relationship among students with different learning styles with respect to achievement in mathematics, and Yilmaz-Soylu and Akkoyunlu [16] said that the type of the learning style was not significantly effective on students’ achievement in different learning environments.

Table 3: Levene’s test of equality of error variances.

\begin{tabular}{|c|c|c|c|}
\hline \multicolumn{4}{|c|}{ Dependent variable: score } \\
\hline F & df1 & df2 & Sig. \\
\hline 1.478 & 5 & 28 & 0.228 \\
\hline
\end{tabular}

Note: Tests the null hypothesis that the error variance of the dependent variable is equal across groups Design: Intercept + style + sex + style * sex

It can be seen from Table 3 that the value of sig.: $0.527>\alpha=0.05$, so, one can say that the variance of cross-group is significantly different.

Table 4: Tests of between-subjects effects. Result of two-way ANOVA.

\begin{tabular}{|l|c|c|c|c|c|}
\hline \multicolumn{7}{|c|}{ Dependent variable: score } \\
\hline Source & Type III sum of squares & $\mathrm{df}$ & Mean square & $\mathrm{F}$ & Sig. \\
\hline Corrected model & $541.540^{*}$ & 5 & 108.308 & 1.233 & 0.320 \\
\hline Intercept & 180427.140 & 1 & 180427.140 & 2054.314 & 0.000 \\
\hline Style & 174.910 & 2 & 87.455 & 0.996 & 0.382 \\
\hline Gender & 64.318 & 1 & 64.318 & 0.732 & 0.399 \\
\hline Style * gender & 345,644 & 2 & 172.822 & 1.968 & 0.159 \\
\hline Error & 2459.195 & 28 & 87.828 & & \\
\hline Total & 226561.000 & 34 & & & \\
\hline Corrected total & 3000.735 & 33 & & & \\
\hline Note: * R squared $=0.180$ (adjusted r squared $=0.034)$
\end{tabular}

The results in Table 4 show the value of sig. in the corrected model: $0.320>\alpha=0.05$. This means that there is no relationship between the independent variables (learning styles, genders and interaction of learning styles with genders) with learning achievement in 1st year of SMAN 1 Galesong Selatan, Indonesia. 
In this table, it is also shown that the value of sig. in variables of learning styles, genders, interaction of learning styles with genders is greater than $\alpha=0.05$. This means that learning styles have no influence over learning achievement, and gender has no influence on learning achievement, and there is no influence of interaction of learning styles and genders to learning achievement in 1st year of SMAN 1 Galesong Selatan, Indonesia.

\section{CONCLUSIONS}

The results of this study showed that 1 ) the learning styles of visual and auditory learning styles is dominated by female students; and 2) there is no relationship between learning styles, genders and interaction of learning styles with genders to learning achievement.

\section{REFERENCES}

1. Rahman, A. and Ahmar, S., Exploration of mathematics problem solving process based on the thinking level of students in junior high school. Inter. J. Environ. Science Educ., 11, 7278-7285 (2016).

2. Rahman, A., Ahmar, A.S. and Rusli, The influence of cooperative learning models on learning outcomes based on students' learning styles. World Trans. on Engng. and Technol. Educ., 14, 3, 425-430 (2016).

3. Gholami, S. and Bagheri, M.S., Relationship between VAK learning styles and problem solving styles regarding gender and students' fields of study. J. of Lang. Teach. Res., 4, 700-706 (2013).

4. Gilakjani, A.P. and Ahmadi, S.M., The effect of visual, auditory, and kinesthetic learning styles on language teaching. Proc. Inter. Conf. on Social Science and Huminity, 5, 469-472 (2011).

5. Naurzalina, D., Karimova, A., Sarkulov, M. and Tolegenova, A., Cognitive style and gender differences in spatial abilities. The European Proc. of Social \& Behavioural Sciences, 95-105 (2015).

6. Mills, C.J., Ablard, K.E. and Stumpf, H., Gender differences in academically talented young students' mathematical reasoning: patterns across age and subskills. J. of Educ. Psychol., 85, 340-346 (1993).

7. Fennema, E., Carpenter, T.P., Jacobs, V.R., Franke, M.L. and Levi, L.W., A longitudinal study of gender differences in young children's mathematical thinking. Educational Researcher, 27, 6-11 (1998).

8. Halpern, D.F., Benbow, C.P., Geary, D.C., Gur, R.C., Hyde, J.S and Gernsbacher, M.A., The science of sex differences in science and mathematics. Psycholological Science in the Public Interest, 8, 1-51 (2007).

9. Benbow, C.P. and Stanley, J.C., Sex differences in mathematical reasoning ability: more facts. PubMed, 2, 222, 1029-1031 (1983).

10. Leder, G.C., Forgasz, H.J. and Taylor, P.J., Mathematics, gender, and large scale data: new directions or more of the same? Proc. 30th Conf. of the Inter. Group for the Psychology of Mathematics Educ., 4, 33-40 (2006).

11. DePorter, B. and Hernacki, M., Quantum learning. (Dell Paperbacks) (2002).

12. Widiyanti, T., Pengaruh gaya belajar terhadap kemampuan pemecahan masalah matematika. UIN Jakarta, Indonesia (2011) (in Indonesian).

13. Kharb, P., Samanta, P.P., Jindal, M. and Singh, V., The learning styles and the preferred teaching - learning strategies of first year medical students. J. of Clin. Diagnostic Research, 7, 1089-1092 (2013).

14. Csapo, N. and Hayen, R., The role of learning styles in the teaching/learning process. Issues Infor. Systems, 7, 129-133 (2006).

15. Ahmad, S., Safee, S., Mohamad, W., Bin, A. and Afthanorhan, W., Learning styles towards mathematics achievements among higher education students. Global J. of Math. Anal., 2, 50-57 (2014).

16. Yilmaz-Soylu, M. and Akkoyunlu, B., The effect of learning styles on achievement in different learning environments. Turkish Online J. of Educ. Technol., 8, 43-50 (2002). 